\title{
Climate findings let fishermen off the hook
}

Quirin Schiermeier, London

Overfishing is not the sole cause of dramatically declining fish stocks in the north Atlantic Ocean, or worldwide, said marine biologists at a Royal Society meeting last week in London. Environmental changes such as climate warming may be just as important, they said, urging governments to consider these factors when managing fisheries.

"Marine ecosystems, particularly in the northern Atlantic, are much more vulnerable to natural fluctuations than previously realized," says Michael Heath, a biologist at the Scottish Fisheries Research Services' Marine Laboratory in Aberdeen, and UK chair of the international project Global Ocean Ecosystem Dynamics (GLOBEC).

The project has substantially improved understanding of the natural mechanisms driving marine productivity and population dynamics, Heath says. This must now be brought to the attention of decision-makers, he adds: "Our measure of success will be how much of the information gathered through GLOBEC is translated into policy-making."

Failure to reconcile ecology and commerce has been a hallmark of international fisheries policy for decades, said biologists at the meeting, which took place as the British government finalizes a widely anticipated report on the future of UK fisheries.

The report is expected to be published later this month by the prime minister's strategy unit and will set out Britain's fisheries management strategy for the next 15-20 years.

But marine biologists say that they have struggled to make their voices heard in the process. GLOBEC participants have provided

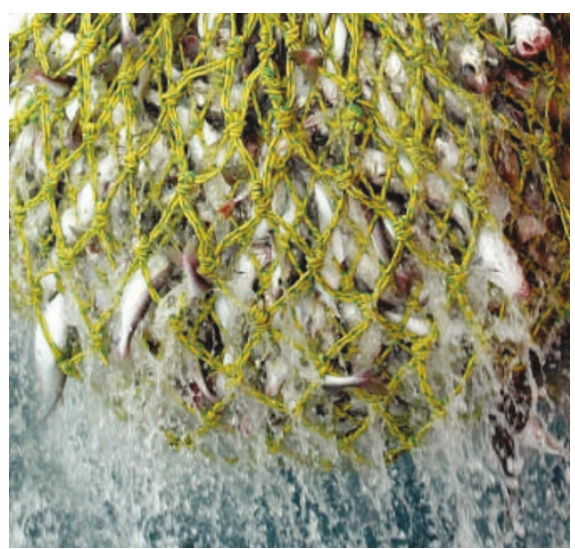

Net effect: fears remain over fisheries' futures.

some input to the report, which may criticize existing practices. But the fishing industry is lobbying equally hard to influence the report.

"The tensions run deep," says Dick James, chief executive of the Northern Ireland Fish Producers' Organisation. "Scientists tend to hold fishermen responsible for anything that happens, but we are certainly not to blame for environmental and climate change. Not all stocks show signs of depletion. We should fish what is there, and fish it responsibly, but we do not get credit for what is going up."

Scientists at the Royal Society meeting called for a concerted effort to ensure that fisheries remain sustainable and profitable.

"With or without environmental trends, fishing mortality, through commercial fishing pressure, is still too high and must be reduced," says Colin Bannister of the UK government's Centre for Environment, Fisheries and Aquaculture Science in Lowestoft.
Scientists involved in GLOBEC, the UK share of which is funded by $\mathfrak{E} 7$ million (US\$13 million) from the Natural Environment Research Council, observed biological responses to environmental changes in marine ecosystems from the Baltic Sea to Antarctica.

"There is evidence for significant decadalscale biological changes, which have major consequences for the abundance of natural resources," says Grégory Beaugrand, a marine biologist at the Sir Alister Hardy Foundation for Ocean Science in Plymouth.

Beaugrand and his team investigated the impact on the marine food web of varying water temperatures and wind strengths in the North Atlantic. They found that fluctuations in the abundance, size and composition of plankton result in long-term changes in the numbers of large, commercially important fish, such as North Sea cod (see Nature 426, 661-664; 2003).

In the past, herring populations in the Baltic Sea and cod stocks off Newfoundland have collapsed, and failed to recover, even after fisheries were closed - indicating that factors other than fishing were in play (see Nature419, 662-665; 2002).

To develop a sustainable fisheries policy, it will be crucial to determine how much of changing mortality patterns is due to fishing operations, and how much to environmental trends, the meeting was told. "If we get this wrong, the penalty to society will be serious," says Martin Angel, a biodiversity researcher at the Southampton Oceanography Centre.

www.pml.ac.uk/globec

www.strategy.gov.uk/output/Page3854.asp

\section{Bush sacks outspoken biologist from ethics council}

\section{Erika Check, Washington}

An eminent cell biologist has been dropped

from the US president's Council on Bioethics after publicly criticizing the administration's stance on stem-cell research.

Elizabeth Blackburn of the University of California, San Francisco, has been told that her two-year term will not be renewed. Three members, including a political scientist, have been added to the council.

Blackburn - discoverer of the enzyme telomerase, which plays an important role in ageing — had disagreed with the council's chairman Leon Kass on issues such as human embryonic stem-cell research, which she supports. She has also claimed that parts of the council's reports on stem-cell research and reproductive technologies have misrepresented scientific facts.

Blackburn says that the online journal
PLoS is about to publish a letter detailing her concerns. She thinks she was removed from the panel because of public disagreements with Kass and the US president George Bush. "I cannot think of any other possible reason," she says.

Critics of the Bush administration interpreted Blackburn's removal as the latest example of a tendency to fill advisory panels with members who support the administration's positions. On 18 February, the Union of Concerned Scientists alleged that such activities are undermining the administration's decisionmaking by distorting scientific information (see Nature 427, 663; 2004).

The Federation of American Societies for
Experimental Biology (FASEB), which represents US biomedical researchers, says that it is "extremely concerned" about Blackburn's removal.

"This decision undercuts the panel's capacity to make recommendations based on the highest quality of information and a broad spectrum of viewpoints," FASEB president Robert Wells wrote in a letter sent to Bush on 1 March.

Kass, a bioethicist at the University of Chicago, says that Blackburn was not removed for her political views, but he declines to elaborate.

"We have people on the council who disagree with the president," Kass says. "He wants diverse opinions and he's got them." 